\title{
DISPOSITION OF FEDERAL RULE 60(b) MOTIONS DURING APPEAL
}

RuLe 60(b) of the Federal Rules of Civil Procedure provides that a district court may grant relief from a judgment or final order. ${ }^{1}$ This rule enables a party to present to a trial court facts which have transpired or become known after entry of judgment and which entitle the movant to a modification of the judgment or a new trial. When appeal is taken, a majority of courts have asserted that the district court loses power to entertain 60 (b) motions, since appeal transfers jurisdiction to the appellate court. ${ }^{2}$ Before the trial court can hear such motions, the party desiring relief must obtain a remand from the appellate court. That court will remand if satisfied that the district court would be justified in modifying its decision. ${ }^{3}$ Recently, however, the Courts of Appeals for the Fifth and District of Columbia Circuits have held that the district court retains limited jurisdiction to consider and deny 60 (b) motions even cluring

1. "On motion and upon such terms as are just, the court may relieve a party or his legal representative from a final judgment, order, or proceeding for the following reasons: (1) mistake, inadvertance, surprise, or excusable neglect; (2) newly discovered evidence which by due diligence could not have been discovered in time to move for a new trial under Rule 59(b); (3) fraud (whether heretofore denominated intrinsic or extrinsic), misrepresentation, or other misconduct of an adverse party; (4) the judgment is void; (5) the judgment has been satisfied, released, or discharged, or a prior judgment upon which it is based has been reversed or otherwise vacated, or it is no longer equitable that the judgment should have prospective application; or (6) any other reason justifying relief from the operation of the judgment. ..." FED. R. CIv. P. 60(b).

2. Zig Zag Spring Co. v. Comfort Spring Corp., 200 F.2d 901, 907-08 (3d Cir. 1953); Baruch v. Beech Aircraft Corp., 172 F.2d 445 (10th Cir.), cert. denicd, 338 U.S. 900 (1949) ; Switzer v. Marzall, 95 F. Supp. 721 (D.D.C. 1951); Daniels v. Goldberg, S F.R.D. 580, 581 (S.D.N.Y. 1948), aff'd zeithout consideration of this point, 173 F.2d 911 (2d Cir. 1949); Schram v. Safety Inv. Co., 45 F. Supp. 636 (E.D. Mich. 1942). Other circuits, while not ruling on $60(\mathrm{~b})$ motions directly, have indicated the same attitude in the analogous situation of motions for new trial under rule 59 pending appeal. See, e.g., Jordan v. Federal Farm Mortgage Corp., 152 F.2d 642 (Sth Cir.), cert. denicd, 328 U.S. 852 (1945) ; Bergeron v. Mansour, 152 F.2d 27 (1st Cir. 1945) ; Isgrig v. United States, 109 F.2d 131 (4th Cir. 1940).

See also Hirsch v. United States, 186 F.2d 524 (Gth Cir. 1951), and Miller v. Unitcd States, 114 F.2d 267 (7th Cir. 1940), cert. denicd, 313 U.S. 591 (1941), holding that a lower court may not grant motions to modify the judgment when appeal is pending. Three district courts, Switzer v. Marzall, supra, Daniels v. Goldberg, supra, and Schram v. Safety Inv. Co., supra, have interpreted Miller to support the view that the lower court loses all jurisdiction, except to act in aid of the appeal. Ferrell v. Trailmobile, Inc., 223 F.2d 697 (5th Cir. 1955), see text at note 4 infra, on the other hand, concedes that Miller bars a lower court from granting such motions, but interprets it to permit a lower court to consider and deny motions.

3. Cf. Isgrig v. United States, supra note 2 .

Presumably a remand will be given unless any decision by the lower court to grant the motion would be erroneous. See text at notes 20-22 infra. 
appeal. ${ }^{4}$ Under this minority procedure, the district court still cannot grant such motions without a remand, but it can indicate an intention to grant, ${ }^{5}$ whereupon a remand may be obtained from the appellate court. ${ }^{\circ}$

Disposition of a motion for relief from a judgment which is being appealed requires a resolution of two competing policies. On the one hand is the traditional rule that only one court can have jurisdiction over a case at one time. ${ }^{7}$ This rule would prohibit a trial court from even hearing motions to modify a judgment while that judgment is being reviewed by an appellate court. On the other hand there is the equally traditional notion that appellate court evaluation should not precede trial court consideration of matters properly within the province of a lower court. ${ }^{8}$ Thus, the lower court should hear and rule on motions before an appellate court considers whether granting the motion

4. Ferrell v. Trailmobile, Inc., 223 F.2d 697 (5th Cir. 1955) ; Smith v. Pollin, 194 F.2d 349 (D.C. Cir. 1952).

The District of Columbia Circuit relied on the procedure already adopted under the Federal Rules of Criminal Procedure, where rule 33 authorizes such limited jurisdiction in case of a motion for a new trial made during appeal. FED. R. CRIMr. P. 33; see Advisory Committee, Federal Rules of Criminal Procedure 131 (2d prelim. draft 1944) (discussing proposed rule 35 which became present rule 33 ).

Possible support for this approach can also be found in a pre-rules decision. Harper v. Klaw, 272 Fed. 894 (2d Cir. 1921). The court held that no permission from the appellate court need be obtained to apply in the district court for leave to file a bill of review; but if the district court granted leave, remand would then be necessary.

5. The district court can give such indication by filing a memorandum opinion, as has been done under rule 33 of the Federal Rules of Criminal Procedure. See United States v. Rakes, 74 F. Supp. 645, 648 (E.D. Va. 1947). The district court, in a memorandum opinion, gave the following indication of intent to grant a motion: "For the reasons stated, I conclude that the motions for a new trial should be granted." The movant then made a motion for remand before the appellate court, and remand was granted on the basis of the lower court's indication. Rakes v. United States, 163 F.2d 771 (4th Cir. 1947), cert. denicd, 335 U.S. 826 (1948).

6. Such remand presumably will not be automatic. See note 10 infra and accompanying text.

7. E.g., Lasier v. Lasier, 47 App. D.C. 80 (D.C. Cir. 1917); Switzer v. Marzall, 95 F. Supp. 721 (D.D.C. 1951).

The basis for this rule apparently lies in the fear that one court may render moot or undermine the other's consideration, if both have simultaneous jurisdiction. See Goldsmith v. Valentine, 35 App. D.C. 299, 301 (D.C. Cir. 1910) ("The effect of the order of the court below might, and probably would, render futile the appeal taken.") ; Star Publishing Co. v. Martin, 47 Del. (8 Terry) 585, 502, 95 A.2d 465, 468 (1953).

8. See, e.g., Hormel v. Helvering, 312 U.S. 552,556 (1941).

This premise is basic to the concept of appellate jurisdiction. Furthermore, in the present situation there exists the practical consideration that an appellate court will find it difficult to decide whether to remand without a complete record, and such a record should be developed in the trial court. Cf. Perlman v. 322 West Seventy-Second Street Co., 127 F.2d 716 (2d Cir. 1942) ; S. C. Johnson \& Son, Inc. v. Johnson, 175 F.2d 176, 180 (2d Cir.) (dissenting opinion), cort. denicd, 338 U.S. 860 (1949); Wright, Anendments to the Federal Rulcs: The Function of a Continuing Rules Committee, 7 VAND. L. REv. 521, 533 (1954). While it is possible that the appellate court could reach a conclusion without a trial court record, this would require introduction of evidence before the appellate court, and, consquently, duplication when the same evidence is required in the lower court. 
would be justified. The majority technique precludes simultaneous exercise of jurisdiction by two courts. While the limited jurisdiction approach of the minority departs from this rule, the deviation is of no consequence. Since the lower court cannot grant such motions without a prior remand, its consideration of the motion cannot undermine the upper tribunal. ${ }^{\circ}$ Unless there is a change in the judgment, the appeal will not be affected, and there can be no change without a remand. In regard to the proper order of consideration, the majority practice reverses the normal sequence by requiring an appellate court to rule on the propriety of what a trial court may do in the future. Under the minority procedure, the appellate court does remand before the motion can be granted, but at least the appellate court evaluates the propriety of a determination already made, though not operative. ${ }^{10}$ The minority procedure therefore can reasonably resolve these competing policies.

The minority approach should be adopted because it offers three practical advantages. ${ }^{11}$ First, the minority procedure eliminates the possibility of forcing a party into an unfair gamble. An appellant may have grounds for a 60 (b) motion which, if successful, will obviate the expense of pursuing his appeal. But to make the motion under the majority approach, he must obtain a remand which terminates his appeal, and must do so without any assurance that the motion will be granted. And since neither a 60 (b) motion nor remand tolls

\section{See note 7 supra.}

10. This evaluation should be the equivalent of the usual appellate review. The upper court should not allow a remand if it might later reverse the granting of the motion. If the motion requests a new trial, an order granting it is considered interlocutory and nonappealable, and is not normally reviewable by an appellate court until a final judgment is entered in the trial court, except where use of a prerogative writ is appropriate. See 7 MLore, Federal Practice $\{$ 60.30[3] (2d ed. 1955); 6 id. If 59.15[2] (2d ed. 1953). However, in the present situation, a departure from this practice is justified, since the case is already before the appellate court.

A record of the motion proceeding will have been prepared in the trial court and can be certified and presented to the appellate court. Thus the party opposing the motion will have an adequate opportunity to persuade the appellate court by brief and argument that the lower court's intended action would be erroneous.

11. The advantages attributed to the minority procedure are also applicable to motions for new trial under rule 59, made when appeal is pending. The situation will arise much less frequently there, however, since rule 59 motions can only be brought within ten days after judgment has been entered. Fed. R. Civ. P. 59; see 6 Moore, Federal Practice If 59.09 [5] (2d ed. 1953).

Related to the problem of motions made while appeal is pending is the separate question of whether permission from the appel'ate court is required to make $60(\mathrm{~b})$ motions after the original judgment has been affirmed. A number of courts have held that such permission is necessary. E.g., Butcher v. Welsh, 205 F.2d 259 (3d Cir. 1953), cert. denicd, 346 U.S. 925 (1954); Home Indemnity Co. v. O'Brien, 112 F.2d 387 (6th Cir. 1940). However, this requirement has been criticized. See Perlman v. 322 West Seventy-Second St. Co., 127 F.2d 716 (2d Cir. 1942); Advisory Comimtrtee, Report of Proposed Amindments to the Rules of Civil Procedure for the Untred States District Courts 62 (1955); Wright, supra note 8, at 532-33; Commentary, 19 FED. RulEs SERv. 1025-28 (1954). But see 7 Moore, Federal Practice ff 60.30[2], 60.42 (2d ed. 1955). 
the period permitted for appeal, ${ }^{12}$ time to commence a new appeal may have expired when the motion is adjudicated. ${ }^{13}$ Therefore, if the motion is denied, the party will have lost his chance for appellate review of the judgment. Yet a 60 (b) motion provides a separate remedy and not a substitute for appeal. ${ }^{14}$ While appeal serves as a review of considerations and conclusions already made by the lower court, a 60 (b) motion presents an extrinsic attack upon the judgment, based on matters not previously before that court. ${ }^{15}$ The two remedies serve different functions, and a party is entitled to both. Under the minority procedure a party need not drop his appeal until the lower court has indicated that it will grant the motion, and a potentially prejudicial choice is thus avoided. ${ }^{16}$ The appellant's predicament could be avoided even under the majority approach, if the appellate court were willing to consider the remand merely a suspension of appeal. ${ }^{17}$ This would allow the appellant to revive his original appeal should the notion be denied after appeal time has expired. Or the same result could

12. Rule 60 (b) specifically provides that "[a] motion under this subdivision ... does not affect the finality of a judgment or suspend its operation." Nor is a 60 (b) motion included among those motions designated in rule 73(a) as tolling appeal time. FED. R. CIv. P. 60(b), 73(a). See also 7 Moore, Federal Practice $\int 60.29$ (2d ed. 1955).

It has been suggested that a $60(\mathrm{~b})$ motion made and considered within the period permitted for appeal does toll the appeal time. 3 Barron \& Holtzoff, Federal Practice and Procedure $\$ 1332$ (1950). This was based upon United States ex rel. Harrington v. Schlotieldt, 136 F.2d 935 (7th Cir. 1943), cert. denied, 327 U.S. 781 (1946). Schlotfoldt, however, did not arise under rule $60(\mathrm{~b})$ as the rule existed at that time, but under an independent motion to vacate. If the same issue were to arise today, it would almost certainly be under rule $60(\mathrm{~b})$, and the Schlotfeldt decision would therefore not be in point. For criticism of Schlotfeldt, see 7 Moore, Federal Practice $\int 60.29$ (2d ed. 1955), and Advisory Committee, Report of Proposed Amendments to the Rules of Civil Procedure for the United States District Courts 97 (2d prelim. draft 1946).

13. The time permitted for filing notice of appeal is thirty days from entry of judgment or sixty days where the United States or an officer thereof is a party; and it may be extended another thirty days upon a showing of excusable neglect. FED. R. CIv. P. 73(a).

A 60 (b) motion may be made within any reasonable time, except that a motion based on (1) excusable neglect, (2) newly discovered evidence, or (3) fraud by an adverse party must be initiated within a year. FED. R. Crv. P. 60(b). See text of rule 60(b) quoted in note 1 supra.

14. See, c.g., Ackermann v. United States, 340 U.S. 193 (1950); Perrin v. Aluminum Co., 197 F.2d 254 (9th Cir. 1952); United States v. Borchers, 163 F.2d 347 (2d Cir.); cert. denied, 332 U.S. 811 (1947).

15. The most common ground for a 60 (b) motion appears to be newly discovered cvidence. See, c.g., Ferrell v. Trailmobile, Inc., 225 F.2d 697 (5th Cir. 1955); Zig Zag Spring Co. v. Comfort Spring Corp., 200 F.2d 901 (3d Cir. 1953). The other grounds, in general, also involve matters arising after judgment has been entered. See note 1 supra.

16. This problem of choice was recognized by the Fifth Circuit: "A party who considercd himself entitled to relief both under Rule $60(\mathrm{~b})$ and also by appeal, might . . . be required to elect between the two remedies, if appeal deprived the district court of jurisdiction to consider the motion under Rule 60(b)." Ferrell v. Trailmobile, Inc., supra note 15 , at 699 .

17. This was done in some criminal cases involving a motion for new trial, prior to the adoption of the present criminal rules. Hamel v. United States, 135 F.2d 969, modificd, 138 F.2d 50 ( (th Cir. 1943) ; Levinson v. United States, 32 F.2d 449 (6th Cir. 1929). 
be achieved by including. in the remand order a provision reserving the right to reinstitute appeal. ${ }^{18}$

Secondly, the limited jurisdiction approach will discourage usurpation by the appellate court of a lower court function. Disposition of a 60 (b) motion is a matter generally within the discretion of the trial court, ${ }^{19}$ and an appellate court should not reverse the trial court's decision unless abuse of discretion can be shown. ${ }^{20}$ Under the majority doctrine the appellate tribunal should therefore remand in all cases where the district court would be justified in granting the motion. ${ }^{21}$ In practice, however, two circuits have based their decisions regarding remand on the far narrower test of whether the district court would be "disposed" to grant the motion. ${ }^{22}$ This in effect removes discretion from the trial court, for it permits an appellate court to deny motions which the lower court might properly grant. Such a result is prevented under the minority system, since the lower court already will have indicated its intention. The appellate court can still overstep its power if, in refusing to remand after such indication, it misuses the "abuse of discretion" test ;23 but it cannot speculate on the predisposition of the lower court, and will be forced to phrase its ruling in terms of the correct test.

Finally, the minority system avoids the possibility of a useless remand. Under the majority approach, if the district court denies a motion after the required remand has been obtained, such remand will have been wasted. The time and effort involved in convincing an appellate court of justification for a remand

18. Such procedure has been suggested by Professor Moore. 7 MoORE, Federal. PracTICE $\{60.30$ [2] (2d ed. 1955).

Both of these alternatives are modifications of the majority procedure, and while they avoid the element of gamble, they retain the other two disadvantages incident to the majority approach making remand prerequisite. See text at notes 19-25 infra.

19. Whether the motion states grounds for relief under rule $60(\mathrm{~b})$, and whether it comes within the time limits of the rule, may be questions of law and not of discretion. See, e.g., Ackermann v. United States, 340 U.S. 193 (1950); 7 Moore, Federal Practice If 60.19 (2d ed. 1955).

20. See, e.g., Bridoux v. Eastern Airlines, Inc., 214 F.2d 207 (D.C. Cir.), cert. denicd, 348 U.S. 821 (1954); Independence Lead Mines Co. v. Kingsbury, 175 F.2d 983 (9th Cir.), cert. denied, 338 U.S. 900 (1949) ; Western Union Tel. Co. v. Dismang, 106 F.2d 362 (10th Cir. 1939). See also 7 Mcore, Federal Practice fi 60.19 (2d ed. 1955).

21. Cf., Isgrig v. United States, 109 F.2d 131. (4th Cir. 1940) (concerning a motion for new trial under rule 59 rather than 60 (b), but involving the same principles).

22. Zig Zag Spring Co. v. Comfort Spring Corp., 200 F.2d 901, 908 (3d Cir. 1953); Baruch v. Beech Aircraft Corp., 172 F.2d 445 (10th Cir.), cert. denied, 338 U.S. 900 (1949). The Tenth Circuit held that it must be "reasonably apparent that with the facts before it, the trial court would be disposed to grant a new trial." This was quoted approvingly by the Third Circuit, which went on to find that in the case at bar it was not "probable" that the district court would grant the motion.

23. "Abuse of discretion" is nccessarily a vague test which an appellate court may use as a veil while substituting its own evaluation of the facts for that of the district court. An appellate court would, perhaps, be more likely to limit a lower court's discretion in order to reverse a denial of a motion. See Bridoux v. Eastern Airlines, Inc., 214 F.2d 207, 210 (D.C. Cir.), cert. denied, 348 U.S. 821 (1954). 
may be considerable, ${ }^{24}$ and eliminating this useless expenditure is significant. The minority treatment, avoids such possible waste, since the remand is not requested until after the lower court has decided to grant the motion. This has been the principal ground for codifying the limited jurisdiction method in the Federal Rules of Criminal Procedure. ${ }^{2 \bar{J}}$ However, a similar defect exists in the minority approach, because the lower court's consideration of the motion will be wasted in cases where the upper court later refuses to permit a remand. Hence, where the lower court would grant the motion, but the upper court would refuse to remand, the majority system is preferable; where the upper court would remand, but the lower court would deny the motion on the merits, the minority system is preferable. Where neither court would give approval as a matter of law, or where the motion would be granted and approved, there is no waste under either approach and no basis for preference. Between the first and second possibilities, the situation of a lower court desiring to grant the motion but an upper court refusing to remand will be less frequent. Such situation will occur only if the district court does in fact abuse its discretion. Consequently, this advantage of the minority solution outweighs the disadvantage and makes this approach more desirable than that of the majority.

Two phases of the minority doctrine not considered in either the District of Columbia or Fifth Circuit decisions should be clarified. The indication of intent by the lower court should be made binding on that court. Unless this is done, the district court could indicate intent to grant and then decide to deny after the remand. ${ }^{2 b}$ As a result the remand would be wasted and in addition appeal might again be lost. The district court can be held to its indication eitlier by including appropriate instructions in the mandate or by so specifying in rule $60(\mathrm{~b}) .27$ Secondly, notice should be given the appellate court at the time the 60 (b) motion proceedings are commenced in the lower court. This will allow the upper court to decide whether to postpone further action on the appellate level, thereby avoiding expense which would become unnecessary if the $60(\mathrm{~b})$ motion were granted. ${ }^{28}$

24. Some appellate courts will examine the merits of the motion in detail before permitting remand. See Zig Zag Spring Co. v. Comfort Spring Corp., 200 F.2d 901 (3d Cir. 1953) ; Baruch v. Beech Aircraft Corp., 172 F.2d 445 (10th Cir.), cert. denied, 338 U.S. 900 (1949).

25. Sce note 4 supra; Advisory Committee, Federat Rules of Criminal Procedure 131 (2d prelim. draft 1944) ; Dession, Nezu Rules of Criminal Procedure: II, 56 Y ALE L.J. 197,232 (1947).

26. While no report of such situation has been found, the possibility would not be unlikely if a different district judge were to hear the motion on remand.

27. See Rakes v. United States, 163 F.2d 771, 773 (4th Cir. 1947), cert. denied, 335 U.S. 826 (1948), where the appellate court included instructions in the mandate under analogous criminal procedure. The appellate court ordered the cause "remanded to the District Court to the end that a new trial be granted ... in accordance with his findings and recommendation. ..."

28. In the rare case where the appeal has been argued, with an appellate opinion about to be delivered, and where such opinion will render the $60(\mathrm{~b})$ motion unnecessary, 
The advantages of the minority procedure should be secured in all federal courts by a modification of rule $60(\mathrm{~b})$. Unfortunately, the most recent draft of proposed amendments to the rule not only fails to treat the problem directly, 20 but tends to confirm the majority technique. The pertinent section of this amendment provides: "Leave to make the motion need not be obtained from any appellate court except during such time as an appeal from the judgment is actually pending before such court." ${ }^{30}$ The proposal does not specifically rule out the possibility that the lower court may consider and deny the motion during appeal. But the implication is clear that when appeal is pending, "leave to make the motion" is required, and consequently the lower court cannot even hear motions without a prior remand..$^{31}$ If this interpretation is correct, the amendment will establish the potentially unjust and wasteful majority procedure and will do so by implication rather than by direct consideration of the problem. The amendment should be redrafted to codify the limited jurisdiction procedure developed by the Fifth and District of Columbia Circuits and already established under the federal criminal rules. ${ }^{32}$

the upper court should not postpone its action. Instead, it should notify the district court of this fact, and the district court, in turn, could postpone the 60 (b) motion.

Moore recommends that the appellate court be notified at the start of limited jurisdiction procedure, in regard to motions under rule 59. The emphasis there, however, is upon the necessity of tolling the ten day period within which request for remand must be made. See 6 Moore, Federal Practice $\{59.09$ [5] (2d ed. 1953). The same reasoning is not applicable to rule $60(\mathrm{~b})$, where the period allowed for remand is longer. See note 13 supra.

29. The Advisory Committee on Rules for Civil Procedure was concerned with the related problem of whether permission is required from the appellate court to reopen a judgment which has already been settled on appeal. Advisory COMMITTEe, REFoRT OF Proposed Amenduents to the Rules of Civil Procedure for the United States District Courts 62 (1955).

These proposals have been passed by the Advisory Committee and now await consideration by the Supreme Court.

30. Id. at 61.

31. The same reasoning which led the Advisory Committee to recommend that no permission be required after appeal is settled should support adoption of the minority approach when appeal is pending. The Advisory Committee states that the appellate court cannot know whether the requirements for reopening a case are actually met without a full record, which must be made in the district court. Id. at 62 . When an appeal is pending, such record should also be made in the district court first, and this is done only under the limited jurisdiction approach. See note 8 supra.

32. The minority procedure could be incorporated into the present amendment, by changing the phrase "make the motion" to "have the motion granted." It would be preferable, however, to establish limited jurisdirtion procedure by a direct and affirmative provision. 